\title{
Response of Net Ecosystem Productivity of Three Boreal Forest Stands to Drought
}

\section{Journal Article}

\section{Author(s):}

Kljun, N.; Black, T.A.; Griffis, T.J.; Barr, A.G.; Gaumont-Guay, D.; Morgenstern, K.; McCaughey, J.H.; Nesic, Z.

Publication date:

2007-09

Permanent link:

https://doi.org/10.3929/ethz-b-000065852

\section{Rights / license:}

In Copyright - Non-Commercial Use Permitted

\section{Originally published in:}

Ecosystems 10(6), https://doi.org/10.1007/s10021-007-9088-x 


\title{
Response of Net Ecosystem Productivity of Three Boreal Forest Stands to Drought
}

\author{
N. Kljun, ${ }^{1, *, \dagger}$ T. A. Black, ${ }^{1}$ T. J. Griffis, ${ }^{2}$ A. G. Barr, ${ }^{3}$ D. Gaumont-Guay, ${ }^{1}$ \\ K. Morgenstern, ${ }^{1}$ J. H. McCaughey, ${ }^{4}$ and Z. Nesic ${ }^{1}$
}

${ }^{1}$ Biometeorology Group, Faculty of Land and Food Systems, University of British Columbia, Vancouver, British Columbia V6T 1Z4, Canada; ${ }^{2}$ Department of Soil, Water, and Climate, University of Minnesota, 1991 Upper Buford Circle, St. Paul, Minnesota 55108, USA; ${ }^{3}$ Meteorological Service of Canada, 11 Innovation Blvd., Saskatoon, Saskatchewan S7N 3H5, Canada; ${ }^{4}$ Department of Geography, Queen's University, Kingston, Ontario K7L 3N6, Canada

\section{ERRATUM TO: ECOSYSTEMS}

DOI 10.1007/s10021-005-0082-X

This article, pulished online with errors, is reprinted here in its entirely. 


\begin{abstract}
In 2000-03, continuous eddy covariance measurements of carbon dioxide $\left(\mathrm{CO}_{2}\right)$ flux were made above mature boreal aspen, black spruce, and jack pine forests in Saskatchewan, Canada, prior to and during a 3-year drought. During the 1st drought year, ecosystem respiration $(R)$ was reduced at the aspen site due to the drying of surface soil layers. Gross ecosystem photosynthesis (GEP) increased as a result of a warm spring and a slow decrease of deep soil moisture. These conditions resulted in the highest annual net ecosystem productivity (NEP) in the 9 years of flux measurements at this site. During 2002 and 2003, a reduction of $6 \%$ and $34 \%$ in NEP, respectively, compared to 2000 was observed as the result of reductions in both $R$ and GEP, indicating a conservative response to the drought. Although the drought affected most of western Canada, there was considerable spatial variability in summer rainfall over the $100-\mathrm{km}$
\end{abstract}

extent of the study area; summer rainfalls in 2001 and 2002 at the two conifer sites minimized the impact of the drought. In 2003, however, precipitation was similarly low at all three sites. Due to low topographic position and consequent poor drainage at the black spruce site and the coarse soil with low water-holding capacity at the jack pine site almost no reduction in $R$, GEP, and NEP was observed at these two sites. This study shows that the impact of drought on carbon sequestration by boreal forest ecosystems strongly depends on rainfall distribution, soil characteristics, topography, and the presence of vegetation that is well adapted to these conditions.

Key words: boreal forest; carbon dioxide; drought; eddy covariance; Fluxnet Canada Research Network; interannual climate variability; soil moisture content.

\section{INTRODUCTION}

The boreal region forms a nearly continuous circumpolar belt of forest extending between $50^{\circ}$ and $70^{\circ} \mathrm{N}$ in North America, Europe, and Asia. This forest covers some 12 million square kilometers and constitutes the world's second largest forested biome (after the tropical forest) (Landsberg and Gower 1997). Recent studies suggest that the boreal region plays an important role in regulating the climate of the northern hemisphere and in the global carbon (C) cycle (for example, Keeling and others 1996).

The boreal forest is characterized by long, severe, and dry winters and short, moderately warm, and moist summers. It consists of either pure or mixed stands of deciduous and coniferous trees, as well as wetlands. The diversity of boreal species is relatively low given the recent glacial history and the slow rate at which species migrate and evolve (McClone 1996). Boreal ecosystems are expected, therefore, to be sensitive to the midcontinent warming and drying forecasted by most global change models (Albritton and others 2001).

During the last decade, considerable attention has been drawn to the interactions between the boreal forest and the atmosphere and the impact of climate change on boreal forest $\mathrm{C}$ cycling. The first major boreal forest $\mathrm{C}$ cycle investigation was the Boreal Ecosystem-Atmosphere Study (BOREAS), a large-scale international interdisciplinary field experiment in the boreal forest of Canada, that was conducted between 1993 and 1996 (Black and others 1996; Baldocchi and Vogel 1997; Sellers and others 1997). In 1997, the Boreal Ecosystem Research and Monitoring Sites (BERMS) program was initiated to continue the long-term monitoring of climate and forest-atmosphere interactions at three of the southern BOREAS sites. In 2002, these sites became part of the Fluxnet Canada Research Network (FCRN). They represent one of the longest continuous records of carbon dioxide $\left(\mathrm{CO}_{2}\right)$ exchange for the three dominant species of the boreal forest-namely, trembling aspen (Populus tremuloides Michx.), black spruce (Picea mariana Mill.), and jack pine (Pinus banksiana Lamb).

The sites are all located within extensive mature stands that are situated within $100 \mathrm{~km}$ of each other. The proximity of these sites provides a unique opportunity to compare the responses of the three ecosystems to similar interannual climate variability. Several studies (Black and others 2000; Arain and others 2002; Griffis and others 2003) have shown that the net ecosystem productivity (NEP) of these forests depends on spring temperature, which determines the start of the growing season, and midsummer temperature, which can cause a marked increase in ecosystem respiration $(R)$. However, during the period addressed by these studies, there were no significant changes in soil 
water availability. Thus we still have only a poor understanding of how these forest types might respond to potential climate change (that is, to warmer and drier conditions than present). The demarcation between the southern boreal forest and temperate grassland is determined by moisture stress (Sellers and others 1997; Hogg 1997). The C budget at the southern boreal tree line may therefore be highly sensitive to climate variations. When Griffis and others (2003) compared the annual NEP of the three sites in 2000, they found strong phenological differences between the deciduous and the evergreen ecosystems. They hypothesized that warmer and drier conditions would reduce the photosynthetic efficiency and C fixation rate of the deciduous stands, thereby reducing their sink strength. They also hypothesized that the high water table at the black spruce sites would prevent strong reductions in tree photosynthesis, but reduced water table position resulting from warmer and drier conditions could have an important negative impact on moss (bryophyte) photosynthesis. Furthermore, heterotrophic respiration is expected to decrease substantially with drier soil conditions, whereas autotrophic respiration is expected to be conservative and proportional to gross ecosystem photosynthesis (Griffis and others 2004).

The goal of the present study was to analyze how environmental variables regulate ecosystem $\mathrm{CO}_{2}$ exchange, focusing on the differences in the responses of the three ecosystems. The selected years (2000-03) are a unique sequence in that they start with a year when temperatures and precipitation were close to the long-term (30-year) average. The subsequent years were affected by a combination of a drought in western Canada (Lotsch and others 2005) and the occurrence of an early or late spring. The two objectives of this paper are to (a) compare the effects of the 3-year drought on the $\mathrm{C}$ balance of the deciduous and conifer stands, and (b) assess the impact of warm and cold springs on the $\mathrm{C}$ balance of these stands relative to the impact of the drought.

\section{Sites, Instrumentation, And Data ANALYSIS}

\section{Site Descriptions}

The three sites are located in the southern boreal forest of Saskatchewan, Canada. They were established in 1993, at the start of BOREAS, and are referred to as Southern Old Aspen (SOA), Southern Old Black Spruce (SOBS), and Southern Old Jack
Pine (SOJP). The SOA site, which is in Prince Albert National Park, is $70 \mathrm{~km} \mathrm{NW}$ of Prince Albert and approximately $80 \mathrm{~km}$ WSW of SOBS, whereas SOJP is about $30 \mathrm{~km}$ ESE of SOBS (Table 1).

Flux measurements at SOA have continued since the completion of BOREAS, in 1996, to the present. Flux measurements at SOBS and SOJP were reestablished in 1999.

The annual mean air temperature in the study area was $0.4^{\circ} \mathrm{C}$, and the annual precipitation was $467 \mathrm{~mm}$ (30-year record 1971-2000 at Waskesiu Lake, Environment Canada, $20 \mathrm{~km}$ north of SOA). The long-term record of the monthly mean air temperature shows a maximum in July $\left(16.2^{\circ} \mathrm{C}\right)$ and a minimum in January $\left(-17.9^{\circ} \mathrm{C}\right)$. The sites receive most of their precipitation during the summer months.

The terrain of the three sites is predominantly flat. All three stands resulted from natural regeneration after wildfires that occurred in 1919, 1879, and 1929 at SOA, SOBS, and SOJP, respectively. Postfire tree establishment depends on disturbance history and species composition at the time of fire, as well as the physical, chemical, and biological characteristics of the soil. Trembling aspen grows in a wide range of soil conditions; however, soil water drainage is necessary. Aspen is quick to pioneer disturbed sites where there is bare soil. Regeneration occurs mainly from suckers, which can survive extreme fire events. Black spruce is commonly found on organic soils with persistently occurring high water tables. Jack pine is found primarily on sandy soils. It is well adapted to dry sandy or gravelly soils where other tree species find it difficult to survive. Regeneration of conifer species occurs mainly from cones and is promoted by fire events (Burns and Honkala 1990).

The aspen stand at SOA is even-aged trembling aspen except for some scattered balsam poplar (Populus balsamifera L.). The soil is moderately well drained. The water table is at a depth of approximately $3 \mathrm{~m}$, and the root zone has a high available soil water storage capacity. The uniform fetch of the flux tower is at least $3 \mathrm{~km}$ in all directions. The black spruce stand at SOBS is fairly uniform in age and is comprised largely of black spruce, with approximately $10 \%$ tamarack (Larix laricina Du Roi) and a very few jack pine. The SOBS site has poor drainage; the water table is near the surface because the site is located in a topographic depression over a scale of $10 \mathrm{~km}$. Vegetation at this site is thus adapted to wet conditions. The flux tower at SOBS has a uniform fetch in the prevailing wind directions of at least $1.2 \mathrm{~km}$. At the SOJP site, there is a relatively pure jack pine stand. Due to the 
Table 1. Site Characteristics

\begin{tabular}{|c|c|c|c|}
\hline & SOA & SOBS & SOJP \\
\hline Location & $53.63^{\circ} \mathrm{N}, 106.20^{\circ} \mathrm{W}$ & $53.99^{\circ} \mathrm{N}, 105.12^{\circ} \mathrm{W}$ & $53.92^{\circ} \mathrm{N}, 104.69^{\circ} \mathrm{W}$ \\
\hline Elevation [m] & 601 & 629 & 579 \\
\hline Year of last disturbance & 1919 & 1879 & 1929 \\
\hline $\begin{array}{l}\text { Dominant overstory } \\
\text { species }\end{array}$ & $\begin{array}{l}\text { Trembling aspen, } \\
\text { (Populus tremuloides } \\
\text { Michx.) }\end{array}$ & $\begin{array}{l}\text { Black spruce } \\
\quad \text { (Picea mariana Mill.) }\end{array}$ & $\begin{array}{l}\text { Jack pine } \\
\quad \text { (Pinus banksiana Lamb) }\end{array}$ \\
\hline Understory species & $\begin{array}{l}\text { Hazelnut (Corylus cornuta } \\
\text { Marsh.) }\end{array}$ & $\begin{array}{l}\text { Sphagnum (Sphagnum, } \\
\text { fuscum Schimp.) Feathermoss } \\
\text { (Pleurozium spp.) }\end{array}$ & $\begin{array}{l}\text { Reindeer lichen } \\
\quad \text { (Cladina mitis Sandst.) } \\
\text { Green alder (Alnuscrispa Ait.) }\end{array}$ \\
\hline Stand height $[\mathrm{m}]$ & 21 & 11 & 13 \\
\hline Stand density [stems ha $\left.{ }^{-1}\right]$ & 830 & 6350 & 1190 \\
\hline $\begin{array}{l}\text { Leaf area index } \\
\quad\left(\text { total canopy) }\left[\mathrm{m}^{2} \mathrm{~m}^{-2}\right]\right.\end{array}$ & $5.6 \pm 0.5$ & $4.2 \pm 1.0$ & $2.4 \pm 0.2$ \\
\hline Depth of organic layer [m] & $0.05-0.1$ & $0.2-0.3$ & $0.02-0.05$ \\
\hline Mineral layer texture & Loam to clay-loam & Sand and clay & Coarse sand \\
\hline Soil drainage & Moderate & Poor & Good \\
\hline $\begin{array}{l}\text { Belowground carbon } \\
{\left[\mathrm{kg} \mathrm{C} \mathrm{m}^{-2}\right]}\end{array}$ & 6.9 & 40.2 & 3.7 \\
\hline $\begin{array}{l}\text { Total ecosystem carbon } \\
\quad\left[\mathrm{kg} \mathrm{C} \mathrm{m} \mathrm{m}^{-2}\right]\end{array}$ & 15.8 & 44.6 & 6.9 \\
\hline $\begin{array}{l}\text { Height of eddy covariance } \\
\text { sensors [m] }\end{array}$ & 39 & 25 & 28 \\
\hline
\end{tabular}

Sources: Baldocchi and Vogel (1997), Blanken and others (1997), Gower and others (1997), Jarvis and others (1997), Ryan and others (1997).

coarse-textured soil, this site is well drained. The water table is very deep, and the vegetation is adapted to dry conditions. The uniform fetch at this site extends beyond $1 \mathrm{~km}$ in all directions. At all three sites, most of the fine roots are in the upper $30 \mathrm{~cm}$ of the soil; the maximum depth of the fine roots is around $60 \mathrm{~cm}$ at SOA and SOBS and $70 \mathrm{~cm}$ at SOJP (A. Kalyn, personal communication). The sites and their ecosystem characteristics are summarized in Table 1. For detailed descriptions of the three sites, see Blanken and others (1997), Jarvis and others (1997), and Baldocchi and Vogel (1997).

Flux footprint estimates were derived using the model of Kljun and others (2004). Footprints under convective conditions (for example, during daytime) typically extended from the tower up to 450 $550,200-300$, and 250-400 m, at SOA, SOBS, and SOJP, respectively $(90 \%$ isopleth in the along-wind direction). During stable or neutral conditions (for example, at night), the footprints typically extended up to 900,500 , and $600 \mathrm{~m}$, at SOA, SOBS, and SOJP, respectively. Thus, daytime and nighttime footprints of the $\mathrm{CO}_{2}$ flux measurements were well within the uniform fetch at all three sites. Griffis and others (2003) found little or no dependence of measured $\mathrm{CO}_{2}$ flux on wind direction at the three sites.

\section{Eddy Covariance Measurements}

At all three sites, $\mathrm{CO}_{2}$ and water vapor $\left(\mathrm{H}_{2} \mathrm{O}\right)$ fluxes were measured using the eddy covariance (EC) technique. The EC sensors were mounted on scaffold towers at approximately twice the canopy height (see Table 1). The sensors included a threedimensional sonic anemometer-thermometer for measuring wind velocity and temperature fluctuations (R3; Gill Instruments Ltd., Lymington, UK, at SOA and SOBS, and CSAT3; Campbell Scientific Inc., Logan, UT, USA, at SOJP), and a closed-path infrared gas analyzer (IRGA 6262; LI-COR Inc., Lincoln, NE, USA) operating in absolute mode for measuring fluctuations in $\mathrm{CO}_{2}$ and water vapor density.

Details about the EC system can be found in Black and others (1996), Arain and others (2002), and Griffis and others (2003). To estimate the change in the $\mathrm{CO}_{2}$ storage in the air column between the forest floor and EC measurement height, $\mathrm{CO}_{2}$ concentration was measured at eight levels between the ground and the EC sensors (Yang and others 1999).

\section{Supplementary Measurements}

Standard climate variables were measured at all three sites (Griffis and others, 2003). Air tempera- 
ture, humidity profiles, and beneath-canopy photosynthetic photon flux density (PPFD) were measured at all three sites. Soil temperature was measured at five depths between 2 and $100 \mathrm{~cm}$ with copper-constantan thermocouples. Volumetric soil water content was measured at 2.5, 7.5, $22.5,45$, and $75 \mathrm{~cm}$ using soil water reflectometers (CS615; Campbell Scientific) and at SOA using time domain reflectometry (TDR) profiles (Moisture-Point; Environmental Sensors Inc., Victoria, BC, Canada). At SOA, leaf area index (LAI) was measured periodically during the growing season using a plant canopy analyzer LAI-2000; LI-COR) (Barr and others 2004). Soil $\mathrm{CO}_{2}$ efflux was measured at all three sites using non-steady-state automated chamber systems, starting in 2000 at SOA and SOBS and in 2002 at SOJP (Drewitt and others 2002; Gaumont-Guay and others 2006).

\section{Data Processing}

Fluxes of $\mathrm{CO}_{2}$ and $\mathrm{H}_{2} \mathrm{O}$ (positive values upward) were calculated as 30-min covariances of the vertical velocity $(w)$ and the mole mixing ratios of $\mathrm{CO}_{2}$ and water vapor (Webb and others 1980). The covariances were calculated as block averages without detrending. A three-dimensional coordinate rotation to align the vertical velocity measurement normal to the mean wind streamlines, thereby bringing the mean vertical and lateral velocity components to zero, was applied following Tanner and Thurtell (1969). The $\mathrm{CO}_{2}$ and $\mathrm{H}_{2} \mathrm{O}$ fluxes at the three sites were corrected for lack of complete energy balance closure by dividing by the fractional energy balance closure $(87 \%, 89 \%$, and $85 \%$ for SOA, SOBS, and SOJP, respectively) (compare Griffis and others 2003). The fractional energy balance closure was calculated as the ratio of the sum of the sensible and latent heat fluxes to the available energy flux.

Net ecosystem exchange (NEE) was then calculated by adding the $\mathrm{EC} \mathrm{CO}_{2}$ flux $\left(F_{C}\right)$, to the rate of change in storage of $\mathrm{CO}_{2}$ in the air column between the forest floor and the EC flux measurement height (Yang and others 1999). Advection terms were neglected in this study. Net ecosystem productivity was obtained from NEP $=-$ NEE. Positive values of NEP correspond to $\mathrm{CO}_{2}$ uptake by the ecosystem, whereas negative values correspond to $\mathrm{CO}_{2}$ loss to the atmosphere.

During the years from 2000 to 2003, the average loss of EC data due to instrument failure was $11 \%$, $13 \%$, and $9 \%$ for SOA, SOBS, and SOJP, respectively. Nighttime fluxes were rejected when the friction velocity, $\mathcal{u}_{*}$, was less than $0.35 \mathrm{~m} \mathrm{~s}^{-1}$ (see, for example, Aubinet and others 2000; Griffis and others 2003). Applying this threshold led to an additional loss of $45 \%, 55 \%$, and $58 \%$ of nighttime data for SOA, SOBS, and SOJP, respectively.

Ecosystem respiration and gross ecosystem photosynthesis (GEP) were derived from NEP measurements. Ecosystem respiration was estimated from (a) growing-season nighttime NEP measurements-that is, $R=-\mathrm{NEP}$-and from (b) nongrowing-season 24-h measurements (defined as $T_{A}$ less than $0^{\circ} \mathrm{C}$ and $T_{S}$ less than $0^{\circ} \mathrm{C}$, where $T_{A}$ is the air temperature and $T_{S}$ is the soil temperature). Values for GEP were obtained from measured NEP and estimated daytime $R$ as GEP $=\mathrm{NEP}+R$. Missing flux data were then filled following the Fluxnet Canada Research Network (FCRN) standard methodology (Barr and others 2004). The core of this methodology is to first derive simple annual empirical relationships (for example, $R=f\left(T_{S}\right)$ ) from measured data, processing one year at a time. An additional parameter is then introduced to account for additional environmental variables or phenological stages that vary over a shorter period of time than an entire year (for example, soil moisture, growing-season length). Accordingly, this parameter was allowed to vary in time, $t$, while the parameters in the annual relationships were held constant. The time-varying parameter was determined within a moving window (100 acceptable data points wide, which corresponded typically to 5-15 days) using a linear regression of estimates modeled from the annual relationship versus measurements. Daytime and missing nighttime $R$ values were calculated from an empirical logistic equation:

$$
R=f\left(T_{S}, t\right)=r_{t}(t) r_{1} /\left[1+\exp \left(r_{2}\left(r_{3}-T_{S}\right)\right)\right]
$$

where $T_{S}$ is measured at the $0.05 \mathrm{~m}$ depth; $r_{t}(t)$ is the time-varying parameter; and $r_{1}, r_{2}$, and $r_{3}$ are the empirical parameters, held constant over the year. Gaps in GEP were filled using the dependence of GEP on down-welling PPFD above the stand, $Q$ (Michaelis-Menten light-response equation):

$$
\mathrm{GEP}=f(Q, t)=p_{t}(t) \alpha Q A_{\max } /\left(\alpha Q+A_{\max }\right)
$$

Here, $p_{t}(t)$ is the time-varying parameter; $\alpha$ is the quantum yield; and $A_{\max }$ is the canopy-scale photosynthetic capacity. Both $\alpha$ and $A_{\max }$ were held constant throughout the year. Finally, NEP was gap-filled using NEP $=$ GEP $-R$.

Annual values of $R$ and GEP depend on the gapfilling method together with the number, size and distribution of data gaps. To estimate the range of uncertainty in these values, the resulting values 
Table 2. Annual Totals of Net Ecosystem Productivity (NEP) Obtained Using Different Gap-filling Methods

\begin{tabular}{|c|c|c|c|c|c|c|c|}
\hline Site & Year & FCRN GF & DLR & AR 1 & AR2 & Avg & SD \\
\hline \multirow[t]{4}{*}{ SOA } & 2000 & 148 & 115 & 134 & 111 & 127 & 17.2 \\
\hline & 2001 & 361 & 322 & 357 & 378 & 355 & 23.6 \\
\hline & 2002 & 139 & 90 & 113 & 93 & 109 & 22.7 \\
\hline & 2003 & 97 & 66 & 95 & 97 & 89 & 15.2 \\
\hline \multirow[t]{4}{*}{ SOBS } & 2000 & 66 & 27 & 53 & 55 & 50 & 16.5 \\
\hline & 2001 & 68 & 30 & 77 & 80 & 64 & 22.9 \\
\hline & 2002 & 21 & -21 & 14 & -17 & -1 & 21.4 \\
\hline & 2003 & 62 & 15 & 68 & 85 & 58 & 29.8 \\
\hline \multirow[t]{4}{*}{ SOJP } & 2000 & 78 & 54 & 81 & 89 & 76 & 15.0 \\
\hline & 2001 & 41 & 28 & 54 & 56 & 45 & 12.9 \\
\hline & 2002 & -23 & -53 & -23 & -8 & -27 & 18.8 \\
\hline & 2003 & 29 & 7 & 31 & 47 & 29 & 16.4 \\
\hline
\end{tabular}

Annual totals of NEP (in $\mathrm{g} \mathrm{C} \mathrm{m}^{-2} \mathrm{y}^{-1}$ ) as derived by the Fluxnet Canada Research Network (FCRN) standard gap-filling method (FCRN GF), the daytime light-response method (DLR) (Griffis and others 2003), and annual respiration (R) and gross ecosystem productivity (GEP) relationships AR1 and AR2 (see Data Processing section). Also shown are the average (Avg) and the standard deviation (SD) of the four estimates.

were tested and compared with values derived from two simple approaches based on empirical annual relationships (AR1 and AR2) and from the daytime light response (DLR) analysis of Griffis and others (2003). ARl uses Eqs. (1) and (2) with the time-varying parameters set to unity as is often done in the literature. AR2 was similar to AR1 except that it was based on an exponential equation for $R$ (for example, Morgenstern and others 2004). For the DLR analysis, missing daytime flux data during the growing season were gap-filled using Eq. (2) (Griffis and others 2003). Table 2 shows the annual totals of NEP obtained using the above methods. Note that the standard deviation does not represent random Gaussian error and therefore cannot be used to assess whether the differences between years are statistically significant. The uncertainty range derived from the above gap-filling methods is in agreement with Griffis and others (2003), who used a Monte Carlo method to estimate the uncertainty of the gap-filling procedure and derived an uncertainty range in NEP (2000) of 64 to 142,18 to 53 , and 61 to $91 \mathrm{~g} \mathrm{C} \mathrm{m}^{-2}$ $\mathrm{y}^{-1}$ for SOA, SOBS, and SOJP, respectively. Independent of the gap-filling method, NEP at SOA was highest in 2001 and very low in 2003. Similarly, at SOBS and SOJP, NEP was lowest in 2002.

Growing-season nighttime EC $\mathrm{CO}_{2}$ fluxes gap filled using the FCRN methodology were compared with the corresponding soil $\mathrm{CO}_{2}$ efflux measurements because the latter generally accounts for a large proportion of nighttime NEE (Gaumont-Guay and others 2006). High correlation between these fluxes was observed for both average nighttime values $\left(r^{2}=0.87,0.92\right.$, and 0.84 at SOA, SOBS,

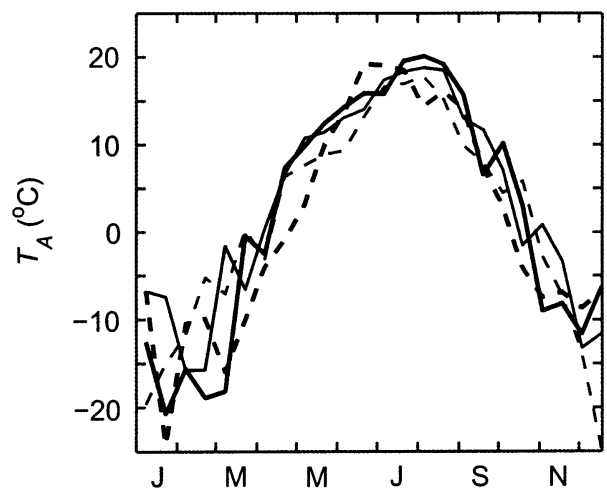

Figure 1. Air temperatures $\left(T_{A}\right)$ (15-day averages) observed at the three sites (average of three sites) in 2000 (dashed thin line), 2001 (solid thin line), 2002 (dashed line), and 2003 (solid line).

and SOJP, respectively) and the temporal variation of the 30-min fluxes. Therefore, for further analysis and discussion, gap-filled values using the FCRN method have been used in this study.

\section{Results AND Discussion}

\section{Seasonal Climate}

From a temperature standpoint, 2000 was a fairly normal year, whereas 2001 was characterized by an early spring with relatively high April-May average $T_{A}$ and $T_{S}$ (Figure 1 and Table 3). In contrast, the spring of 2002 was cold, with temperatures remaining below $0^{\circ} \mathrm{C}$ until the end of April (Figure 1 and Table 3). In 2003, the spring was relatively warm, but $T_{S}$ was very similar to that of 2000. Air temperatures in September were similar 
Table 3. Climate Characteristics

\begin{tabular}{lllllll}
\hline & $1971-2000$ & $1994-2000$ & 2000 & 2001 & 2002 & 2003 \\
\hline Apr-May $T_{A}\left[{ }^{\circ} \mathrm{C}\right]$ & $5.7 \pm 2.5$ & $6.9 \pm 1.8$ & $5.0 \pm 0.7$ & $7.4 \pm 0.4$ & $2.2 \pm 0.3$ & $6.9 \pm 0.3$ \\
Apr-May $T_{S}\left[{ }^{\circ} \mathrm{C}\right]$ & n.a. & $2.8 \pm 0.8$ & $2.3 \pm 1.2$ & $3.0 \pm 0.9$ & $0.5 \pm 0.5$ & $2.3 \pm 0.8$ \\
Annual $T_{A}\left[{ }^{\circ} \mathrm{C}\right]$ & $0.4 \pm 4.7$ & $2.8 \pm 1.3$ & $0.9 \pm 0.5$ & $3.0 \pm 0.2$ & $0.8 \pm 0.3$ & $1.7 \pm 0.4$ \\
Annual $P[\mathrm{~mm}]$ & 467 & $481 \pm 55$ & $449 \pm 61$ & $317 \pm 87$ & $383 \pm 84$ & $271 \pm 16$ \\
May-Sep $P[\mathrm{~mm}]$ & 312 & $318 \pm 73$ & $326 \pm 62$ & $217 \pm 68$ & $266 \pm 75$ & $176 \pm 16$
\end{tabular}

$T_{A}$, air temperature; $T_{S}$, soil temperature; $P$, precipitation.

Values for 1971-2000 are based on the 30-year record at Waskesiu Lake, 53.92 $\mathrm{N}, 106.08^{\circ} \mathrm{W}$, Environment Canada. Values for $1994-2000$ are from averaged measurements at SOA and SD of the annual values. Values for 2000-03 are the average values of measurements at the three sites with the SD of the sites. $T_{A}$ was measured at approximately twice the canopy height, $T_{S}$ at the 5 -cm depth.
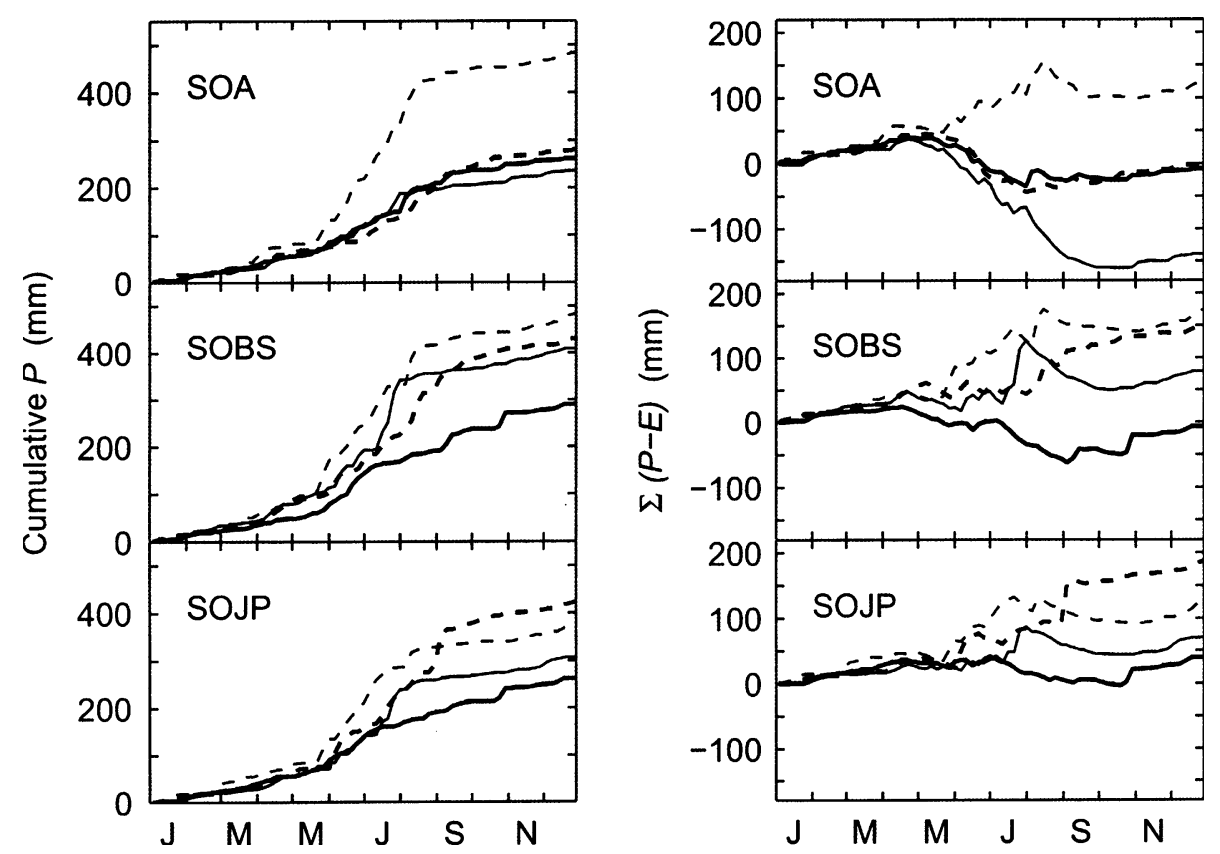

Figure 2. Cumulative precipitation $(P)$ (left panel) and cumulative water balance (precipitation - evapotranspiration) (right panel) observed at the three sites in 2000 (dashed thin line), 2001 (solid thin line), 2002 (dashed line), and 2003 (solid line).

during the 4 years, and no early autumn frosts occurred. Precipitation $(P)$ at the three sites in 2000 was very similar to the $1994-2000$ average at SOA and the 30-year mean (1971-2000) at Waskesui Lake (Table 3). Starting in summer 2001, the three sites were affected by a severe drought that occurred in western Canada and persisted through 2003. During the drought, $P$ was $35 \%$ to $50 \%$ lower than the 30-year mean (Table 3 and Figure 2). Although the sites were exposed to the same mesoscale weather systems, in 2001 and 2002 SOA received significantly less precipitation than the other two sites. In 2003, $P$ was below normal and similar at all three sites.

Several approaches have been used to analyze the effects of drought on vegetation. Baldocchi (1997) introduced an empirical drought index derived from the ratio of cumulative potential evap- oration to cumulative P. Griffis and others (2003) used cumulative $P-E$, where $E$ is the evapotranspiration, as an upper limit of the amount of water available for tree growth. Reichstein and others (2002) suggested using the ratio of volumetric soil water content, $\theta$, to soil water content at field capacity, $\theta_{\mathrm{fc}}$, to determine drought effects. In the present study, relative available soil water content, $\theta_{r}=\left(\theta-\theta_{\mathrm{wp}}\right) /\left(\theta_{\mathrm{fc}}-\theta_{\mathrm{wp}}\right)$, where $\theta_{\mathrm{wp}}$ is the soil water content at the wilting point, is used to characterize the impact of the drought. Generally, plant water uptake remains high until about one-half of the available water has been extracted (Campbell and Norman 1998). Foti and others (2003) found that predawn plant water potential of Miscanthus $\times$ giganteus began to decline markedly when $\theta_{r}$ dropped below 0.5 , suggesting the likely occurrence of water stress for $\theta_{r}$ less than 0.5. 


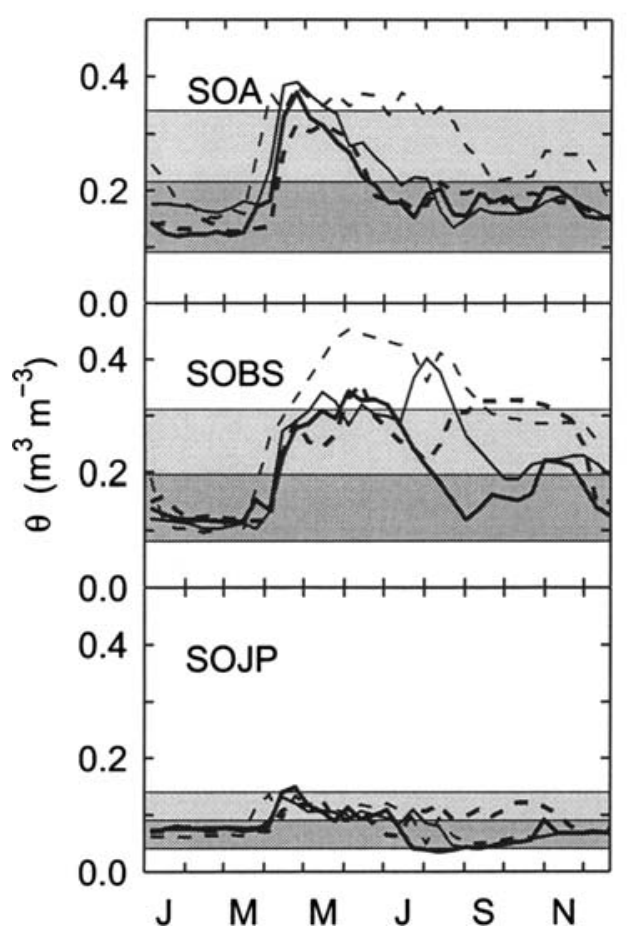

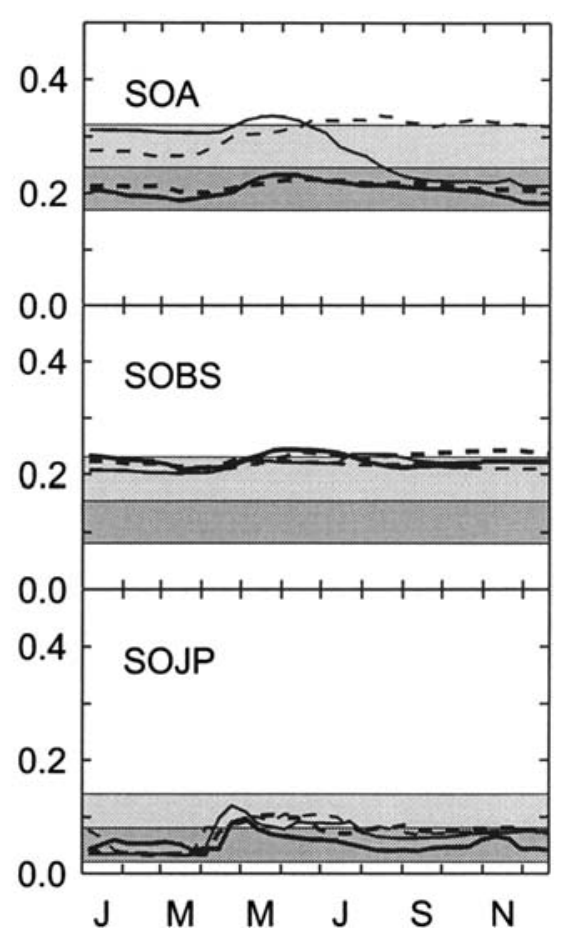

Figure 3. Interannual and seasonal variation in soil moisture content (10-day averages) at the $7.5-\mathrm{cm}$ depth (left panel) and the 30-60-cm depth (right panel) observed at the three sites in 2000 (dashed thin line), 2001 (solid thin line), 2002 (dashed line), and 2003 (solid line). The shaded areas represent the range of the available water fraction between 0 and 0.5 (dark gray) and between 0.5 and 1 (light gray). 0 corresponds to wilting point and 1 to field capacity. Water stress is likely between 0 and 0.5 .
At SOA, $\theta$ at the $7.5-\mathrm{cm}$ depth increased after snowmelt in all 4 years, with $\theta_{r}$ being well above 0.5 (Figure 3). In 2000, $\theta_{r}$ remained high until the end of August. In 2001, it dropped steadily during June, July, and August, reaching 0.5. In 2002 and 2003, $\theta_{r}$ dropped to 0.5 by the end of June and remained well below 0.5 for the rest of the growing season. At the $30-60-\mathrm{cm}$ depth, $\theta$ dropped from about $0.3 \mathrm{~m}^{3} \mathrm{~m}^{-3}$ to $0.2 \mathrm{~m}^{3} \mathrm{~m}^{-3}$ during June, July, and August of 2001 (Figure 3). There was almost no recharging of soil water at lower depths after snowmelt in spring 2002 and spring 2003, and available water deep in the soil profile remained as low as at the end of the 2001 growing season (that is, $\theta_{r}$ less than 0.5$)$. The water table receded from a depth of 3 to $4 \mathrm{~m}$ below the surface over the period 2001-03 (Barr and others 2007).

At SOBS, summer rain events reduced the impact of the drought in 2001 and 2002, and $\theta_{r}$ remained larger than 0.5 throughout the growing seasons of 2000 to 2002. The effect of the drought was most evident in 2003 when $\theta$ at the $7.5-\mathrm{cm}$ depth dropped at the beginning of July and $\theta_{r}$ reached 0.2 at the end of August. In contrast to SOA, $\theta$ at the $30-60-\mathrm{cm}$ depth remained almost constant throughout the 4 years, with a slight increase each year during snowmelt. That there was no marked drop in $\theta$ at this depth reflects the persistently high water table in the surrounding area, resulting in the dominance of black spruce.
At SOJP, $\theta$ at the $7.5-\mathrm{cm}$ depth was at similar levels between April and June for all 4 years. Similar to conditions at SOBS, the water regime at SOJP in 2001 and 2002 was affected by the July and August rain events. In 2003, $\theta_{r}$ at the $7.5-\mathrm{cm}$ depth dropped to zero in mid-July, increasing only slightly during the rest of the growing season. At the $30-60-\mathrm{cm}$ depth, it remained at 0.5 during the 2000-02 growing seasons, whereas in 2003 it fell from 0.4 to 0.2 .

\section{Response of Net Ecosystem Productivity to Climate Conditions}

As indicated above, climate conditions in 2000 were not significantly different from the recent 30-year climate normals. We assumed, therefore, that 2000 could serve as a reference or normal year to help interpret the seasonal and interannual variations in NEP. A comparison of the $\mathrm{CO}_{2}$ fluxes at SOA, SOBS, and SOJP in 2000 with those of previous years (for example, Baldocchi and others 1997; Black and others 2000; Barr and others 2004; Jarvis and others 1997) supported this assumption.

Impact of Spring Temperatures on Net Ecosystem Productivity. Warm spring temperatures in 2001 and 2003 caused leaves to emerge about 2 weeks earlier than in 2000, and this in turn led to an earlier start of photosynthesis (Table 4). Early leaf emergence at SOA was also observed during similar 
Table 4. Growing-season Characteristics

\begin{tabular}{|c|c|c|c|c|}
\hline Year & & SOA & SOBS & SOJP \\
\hline \multirow[t]{3}{*}{2000} & First day & May 16 & March 24 & March 26 \\
\hline & Last day & September 28 & November 4 & November 2 \\
\hline & GS length & 135 & 225 & 221 \\
\hline \multirow[t]{3}{*}{2001} & First day & May 7 & April 3 & April 5 \\
\hline & Last day & September 28 & November 8 & November 14 \\
\hline & GS length & 144 & 219 & 223 \\
\hline \multirow[t]{3}{*}{2002} & First day & May 28 & April 14 & April 22 \\
\hline & Last day & October 6 & October 16 & October 16 \\
\hline & GS length & 131 & 185 & 177 \\
\hline \multirow[t]{3}{*}{2003} & First day & May 11 & March 24 & March 31 \\
\hline & Last day & October 2 & October 30 & November 1 \\
\hline & GS length & 141 & 220 & 215 \\
\hline
\end{tabular}

First and last day of detectable photosynthetic activity (reliability \pm 3 days) and length of growing season (GS) in days (reliability \pm 6 days). The first day of photosynthetic activity was detected from the decrease in daytime eddy covariance (EC) $\mathrm{CO}_{2}$ fluxes below the trend in respiratory fluxes. Daily net ecosystem productivity (NEP) began to increase 2-3 days after this (compare Black and others 2000).
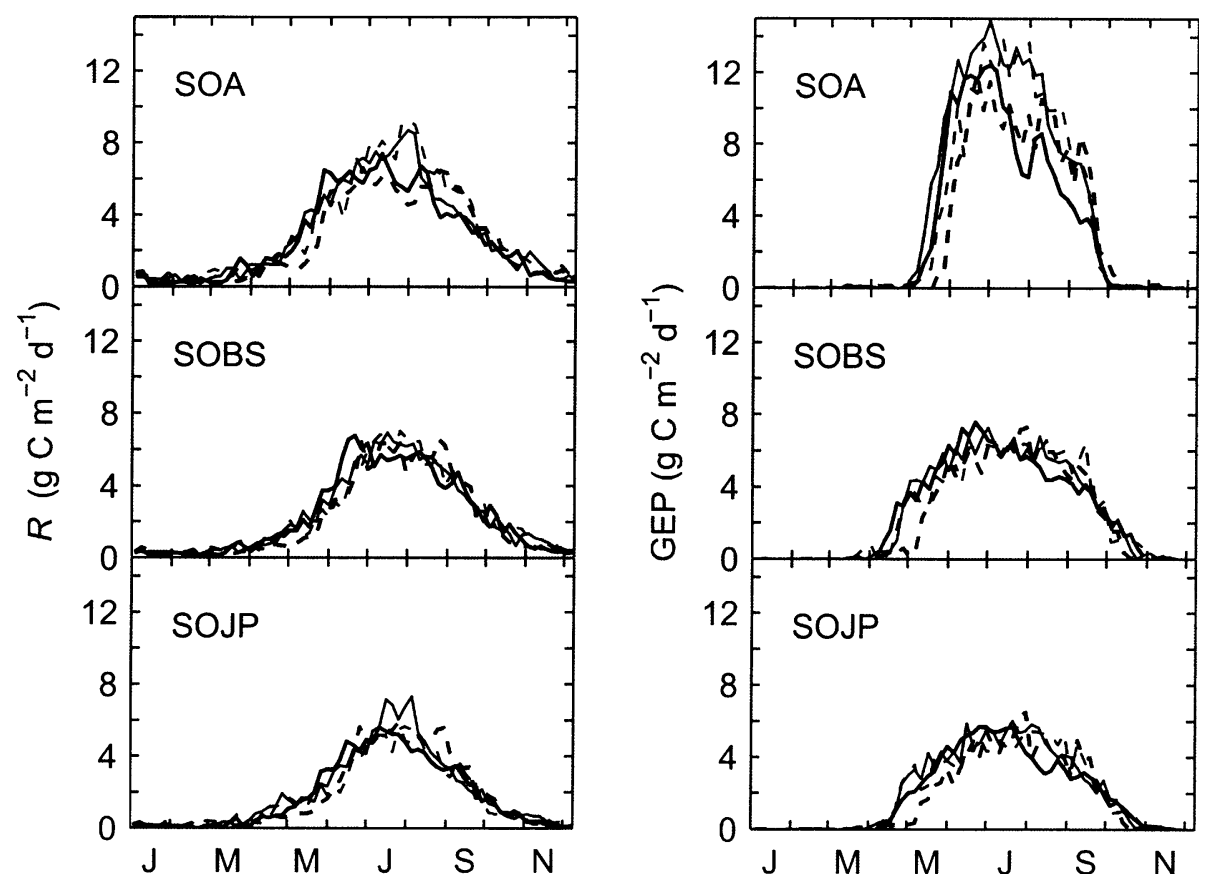

Figure 4. Interannual and seasonal variation in ecosystem respiration $(R)$ (left panel) and gross ecosystem productivity (GEP) (right panel) observed at the three sites in 2000 (dashed thin line), 2001 (solid thin line), 2002 (dashed line), and 2003 (solid line) (5-day averages).

spring conditions in 1998 caused by El Niño (Black and others 2000). Although leaf emergence at SOA in 2003 started as early as in 2001, the maximum LAI (aspen plus hazelnut: $4.0 \mathrm{~m}^{2} \mathrm{~m}^{-2}$ ) was reached 10 days later and was $20 \%$ lower than in 2001 . This suggests that the trees experienced some water stress early in the growing season and fewer aspen clones had started photosynthesizing as early as in 2001 (Barr and others 2004). However, it's also possible that the timing of the leaf emergence was influenced by the spring soil temperature, which was lower in 2003 than in 2001 (compare Baldocchi and others 2005).
Although at SOA the correlation between the date of onset of photosynthesis was highest for April-May average $T_{A}\left(r^{2}=0.94\right)$, at the conifer sites the date of onset of photosynthesis correlated better with $T_{A}$ in March and April $\left(r^{2}=0.62\right.$ and 0.83 for SOBS and SOJP, respectively). In particular, March 2001 was colder than March 2000; consequently, at the conifer sites, photosynthesis in 2001 was initiated 10 days later than in 2000 (Figure 4, right panel). During the warm spring period of 2003, GEP and $R$ at the conifer sites started on almost the same dates as in 2000 (Figure 4). Respiration at the three sites was not sig- 

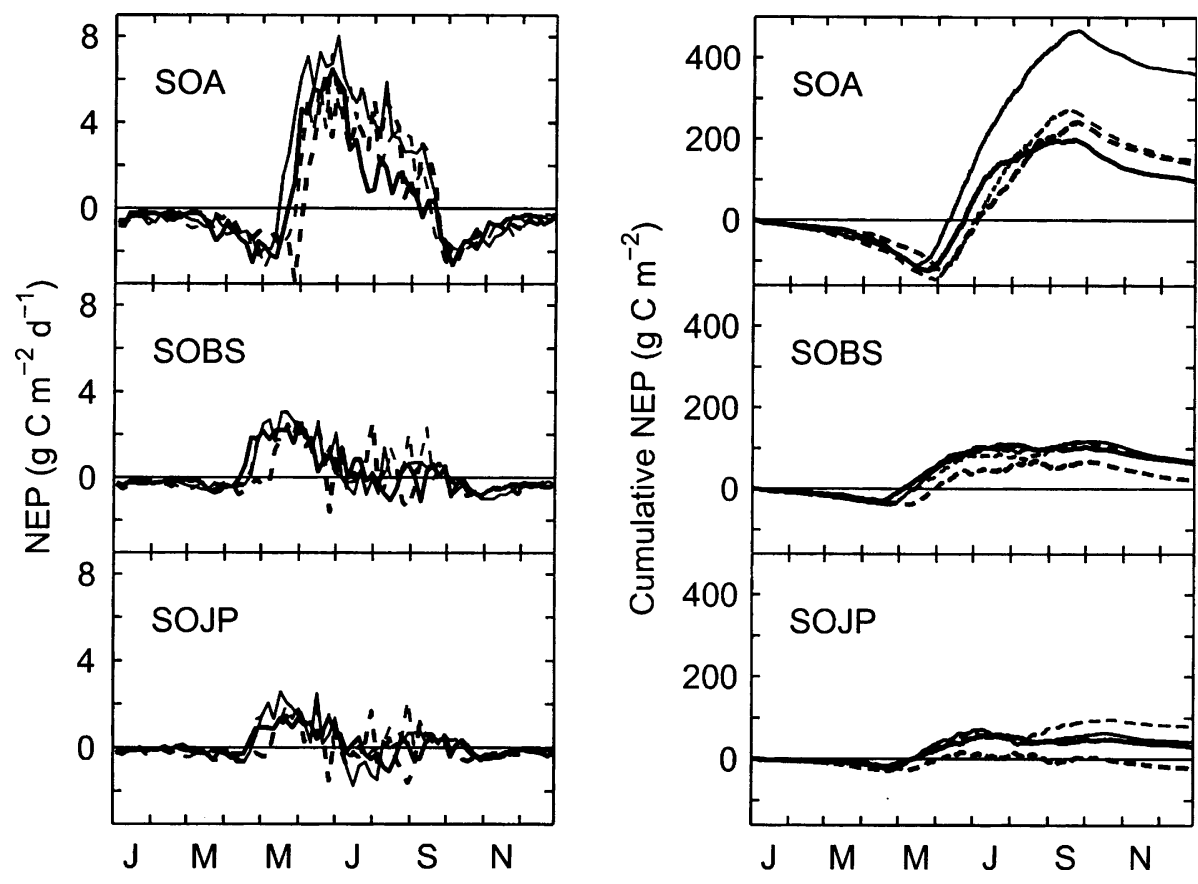

Figure 5. Interannual and seasonal variation in net ecosystem productivity (NEP) (5day averages) observed at the three sites in 2000 (dashed thin line), 2001 (solid thin line), 2002 (dashed line), and 2003 (solid line).

nificantly greater during the warm springs of 2001 and 2003 (Figure 4, left panel) because $T_{S}$ was not significantly higher than in 2000.

During the cold spring of 2002, photosynthetic activity at SOA was initiated 2 weeks later than in 2000. The two conifer sites were also affected by the colder temperatures, such that photosynthetic activity started 3-4 weeks later than in 2000. Respiratory activity was inhibited at all three sites due to the cold spring conditions (Figure 4). For the 4 years analyzed here, the observed changes in NEP during spring corresponded closely to the changes observed for GEP at the three sites (Figure 5).

Impact of Drought On Net Ecosystem Productivity. To separate the effects of spring temperatures and drought, we focus on the analysis of summer fluxes in this section. Instead of using annual or growing-season totals, NEP, GEP, $R$, and $E$ were summed over the part of the growing season that was less directly influenced by a warm or cold spring. To account for the earlier start of photosynthesis (and thus the longer growing season) at the conifer sites compared to the deciduous site, which can only photosynthesize after leaf emergence, the length of this reference growth period (RGP) was site dependent. In the following analysis, the RGP was limited to the period between June 15 and September 30 for SOA, and June 1 to September 30 for the conifer sites. Thus, NEP $\mathrm{rgp}_{\text {rgp }} \mathrm{GEP}_{\text {rgp }}, R_{\text {rgp }}$, and $E_{\text {rgp }}$ represent the totals for this period. Although spring temperature conditions could affect or even amplify the response of the trees to drought later in the growing season, the direct impact of drought would likely outweigh this effect. Figure 6 and Table 5 show NEP rgp, GEP rgp and $R_{\text {rgp }}$ for the 4 years.

For SOA, cumulative $P-E$, was largely negative (Figure 2, right panel), but there was no reduction in $\mathrm{GEP}_{\text {rgp }}$ or $E_{\text {rgp }}$ in the lst year of the drought (2001) (compare Figures 4, 6, and 7 and Table 5). This suggests that the tree roots were able to access water at depths lower than the upper $30 \mathrm{~cm}$, where most fine roots develop. In fact, water balance estimates by Bernier and others (2006) suggest water uptake can occur as deep as $200 \mathrm{~cm}$ at this site. In 2002 and in 2003, GEP rgp dropped by 13\% to $15 \%$ per year and $E_{\text {rgp }}$ by $14 \%$ to $20 \%$ (Figure 6 and Table 5). Maximum daily $E$ and GEP $(Q>$ $1200 \mu \mathrm{mol} \mathrm{m} \mathrm{m}^{-2} \mathrm{~s}^{-1}, 10 \mathrm{AM}$ to $3 \mathrm{PM}$ local time) during the RGP were reduced by $31 \%$ and $28 \%$, respectively, compared to 2000. Barr and others (2004) showed that reduced $\mathrm{GEP}_{\text {rgp }}$ in 2002 and 2003 corresponded to low midsummer aspen LAI values of 2.3 and $1.9 \mathrm{~m}^{2} \mathrm{~m}^{-2}$, respectively, compared to values of around $2.7 \mathrm{~m}^{2} \mathrm{~m}^{-2}$ in 2000 and 2001 . They suggested that these low values were partly due to reduced leaf water potential during leaf emergence.

In contrast to $\mathrm{GEP}_{\mathrm{rgp}}, R_{\mathrm{rgp}}$ at SOA dropped by $10 \%$ in the lst year of the drought (Figure 6). Soil $\mathrm{CO}_{2}$ effluxes also decreased significantly (Griffis and others 2003; Gaumont-Guay and others 2006). 
Table 5. Net Ecosystem Productivity (NEP), Ecosystem Respiration $(R)$, Gross Ecosystem Productivity (GEP), and Evapotranspiration (E) for the Reference Growth Period (RGP)

\begin{tabular}{llcccc}
\hline Site & Year & NEP $_{\text {rgp }}\left[\mathrm{C} \mathrm{m}^{-2} \mathrm{y}^{-1}\right]$ & $R_{\text {rgp }}\left[\mathrm{g} \mathrm{C} \mathrm{m}^{-2} \mathrm{y}^{-1}\right]$ & $\mathrm{GEP}_{\text {rgp }}\left[\mathrm{g} \mathrm{C} \mathrm{m}^{-2} \mathrm{y}^{-1}\right]$ & $E_{\text {rgp }}\left[\mathrm{mm} \mathrm{H}_{2} \mathrm{O} \mathrm{y}^{-1}\right]$ \\
\hline SOA & 2000 & 343 & 708 & 1051 & 269 \\
& 2001 & 429 & 639 & 1068 & 264 \\
& 2002 & 330 & 576 & 907 & 213 \\
SOBS & 2003 & 230 & 559 & 789 & 212 \\
& 2000 & 83 & 604 & 687 & 227 \\
& 2001 & 67 & 606 & 674 & 205 \\
SOJP & 2002 & 65 & 593 & 658 & 203 \\
& 2003 & 47 & 603 & 528 & 176 \\
& 2000 & 65 & 463 & 544 & 164 \\
& 2001 & 19 & 525 & 523 & 175 \\
\end{tabular}

Reference growth period (RGP): period between June 15 and September 30 for SOA, and June 1 to September 30 for the conifer sites. Totals of NEP $P_{r g p}, G E P_{r g p}, R_{r g p}$, and $E_{r g p}$ are given for this period.

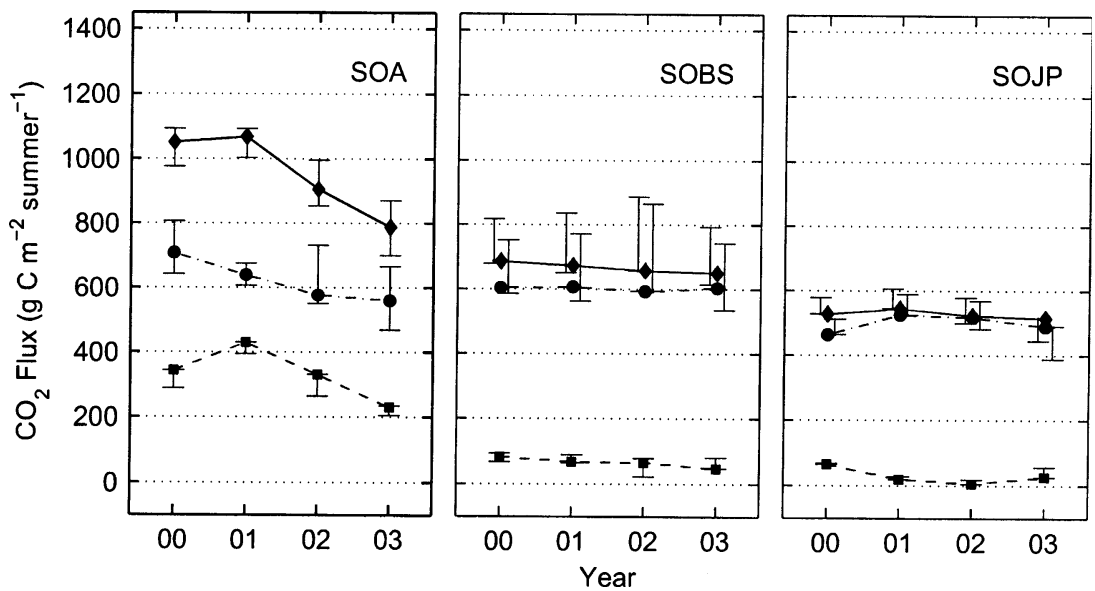

Figure 6. $\mathrm{CO}_{2}$ Fluxes for the reference growth period (RGP). Net ecosystem productivity (NEP $\mathrm{rgp}$ ) (squares, dashed line), gross ecosystem productivity $\left(\mathrm{GEP}_{\mathrm{rgp}}\right)$ (diamonds, solid line), and ecosystem respiration $\left(R_{\mathrm{rgp}}\right)$ (circles, dash dotted line) during the summer months of 2000-03 (SOA, June 15 to September 30; SOBS and SOJP, June 1 to September 30). Vertical bars denote the range of values derived from four gap-filling methods (see Table 2). Where required for clarity, the vertical bars for GEP and $R$ have been moved to the left and right, respectively.

This decrease was likely due to reduced heterotrophic $R$ in the surface soil layer as a result of the pronounced drop in $\theta$ (Figure 3). Any decrease in autotrophic $R$ was likely to be small because there was no decrease in GEP $\mathrm{rgp}$. In the following 2 years, $R_{\text {rgp }}$ further dropped by up to $10 \%$ per year. These reductions were likely caused by decreases in both heterotrophic and autotrophic $R$.

Reichstein and others (2002) argued that the effect of drought on GEP depends largely on how much water is available to roots in the whole soil profile, whereas the effect on $R$ depends mainly on the soil water content and temperature of the upper soil layers. Borken and others (1999) assumed that autotrophic $R$ did not decrease because fineroot growth was not severely affected and that root $R$ had shifted to deeper soil layers to ensure water supply to the trees. Borken and others (2006) found that experimentally induced drought caused a strong reduction in ${ }^{14} \mathrm{CO}_{2}$ soil efflux. This reduction resulted from a decrease in the decomposition of older C substrates (that is, heterotrophic $R$ ) compared to autotrophic $R$. These findings support our hypothesis that the observed reduction in $R_{\mathrm{rgp}}$ at SOA in 2001 was largely due to a decrease in heterotrophic $R$.

The decrease in $R_{\text {rgp }}$ in the 1st year of the drought caused a remarkable $25 \%$ increase in 


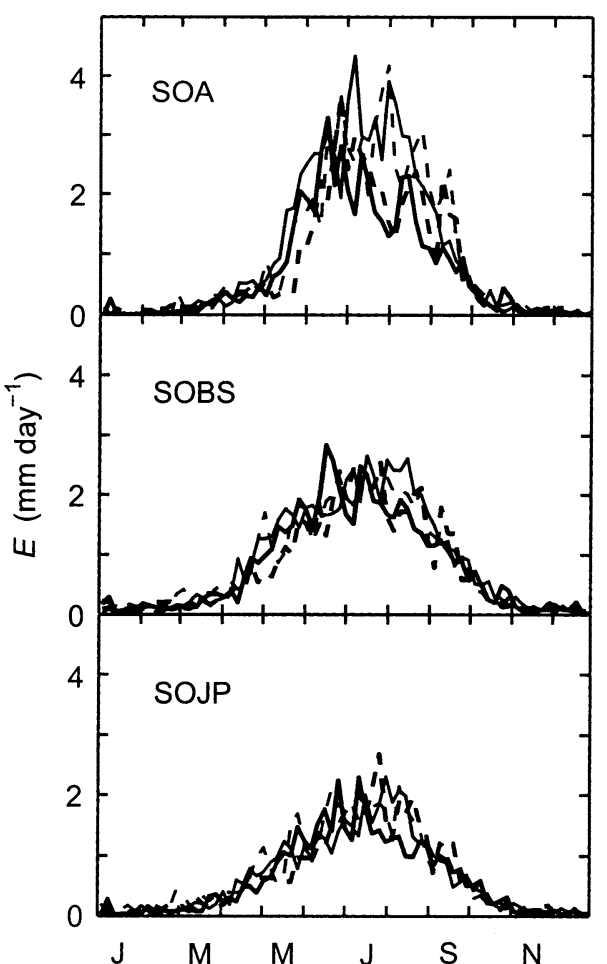

Figure 7. Interannual and seasonal variation in evapotranspiration $(E)$ (5-day averages) observed at the three sites in 2000 (dashed thin line), 2001 (solid thin line), 2002 (dashed line), and 2003 (solid line).

$\mathrm{NEP}_{\text {rgp }}$. This factor contributed significantly to the large increase in annual NEP in that year, as will be discussed later. In the 2nd year of the drought, $\mathrm{NEP}_{\text {rgp }}$ was only slightly lower than before the drought. This was because the drop in $R_{\text {rgp }}$ nearly canceled the decrease in $\mathrm{GEP}_{\mathrm{rgp}}$. In 2003, however, $\mathrm{NEP}_{\text {rgp }}$ was almost a third lower than in 2000 because the drop in $\mathrm{GEP}_{\text {rgp }}$ was much larger than $R_{\text {rgp }}$ (Figure 6). Maximum daily NEP during the RGP was reduced by $38 \%$ compared to 2000 ; this reduction corresponds closely with the drought effects reported by Baldocchi (1997).

In the case of the conifer sites, $\mathrm{GEP}_{\text {rgp }}$ and $R_{\text {rgp }}$ were remarkably constant over the 4 years, showing very little effect of the 3 drought years. Even during the 3rd drought year, when growing-season precipitation was significantly lower than in the first 2 drought years, the effect on $\mathrm{GEP}_{\text {rgp }}$ and $R_{\text {rgp }}$ was hardly detectable given the uncertainty in the calculated values. Slight reductions in GEP and $R$ occurred only in August 2003, when precipitation was very low. With the measured values of NEP ${ }_{\text {rgp }}$, the absolute differences between the 3 drought years and the non-drought year (2000) were small (Table 5). Maximum daily $E$ during the RGP remained unaffected at SOBS and dropped by only $12 \%$ at SOJP. This finding is also in good agreement with Baldocchi and Vogel (1997), who suggested that evapotranspiration is more conservative at the conifer stands than at SOA.

Factors Controlling Ecosystem Respiration, Gross Ecosystem Photosynthesis, and Net Ecosystem Productivity. Figure 8 (left panel) shows the relationships
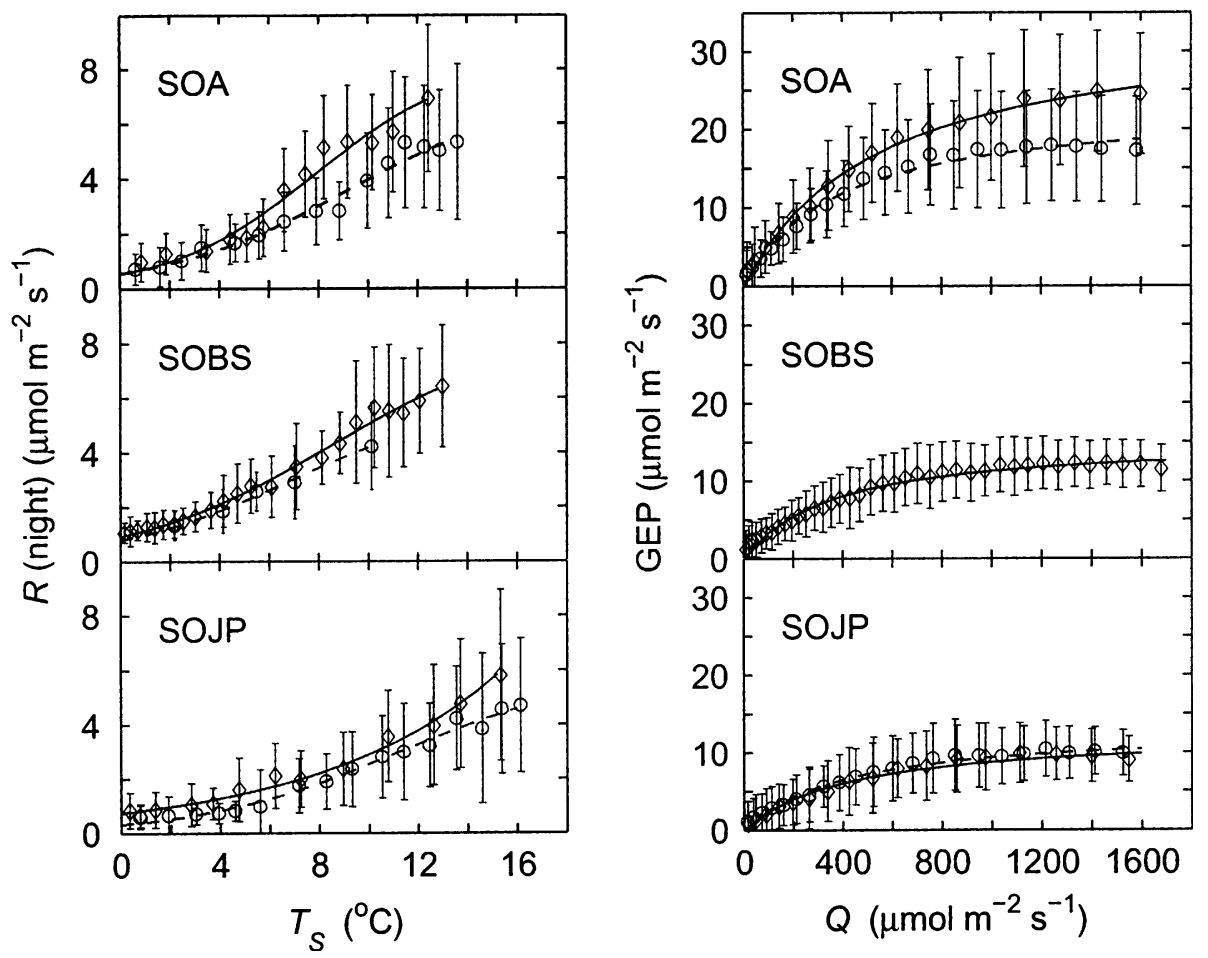

Figure 8. Influence of relative available soil moisture content $\theta_{r}$ on ecosystem respiration $(R)$ and gross ecosystem productivity (GEP). Left panels: Dependence of measured nighttime $R$ on $T_{S}$ (5cm depth) and on $\theta_{r}(7.5-\mathrm{cm}$ depth). Right panels: Dependence of GEP on $Q$ and $\theta_{r}$ at the 30-60cm depth. $\theta_{r}$ greater than (solid line, diamonds) or less than or equal to (dashed line circles) $50 \%$. Symbols denote bin-averages of 200 and 350 data points of $R$ and GEP, respectively. Lines are fits (Eqs. [1] and [2]) through 30min data (see Table 6). Error bars denote the SD within each bin. 
Table 6. Parameters of Eqs. (1) and (2) for Dry and Moist Conditions

\begin{tabular}{|c|c|c|c|c|c|c|c|c|}
\hline \multirow[t]{2}{*}{ Site } & \multirow[t]{2}{*}{ Condition } & \multicolumn{4}{|c|}{$T_{s}$ versus $R$ (night), EQ. (1) } & \multicolumn{3}{|l|}{$Q$ versus GEP, Eq. (2) } \\
\hline & & $r_{1}\left[\mu \mathrm{mol} \mathrm{m}{ }^{-2} \mathrm{~s}^{-1}\right]$ & $r_{2}\left[{ }^{\circ} \mathrm{C}^{-1}\right]$ & $r_{3}\left[{ }^{\circ} \mathrm{C}\right]$ & $R^{2}[-]$ & $\alpha\left[\mathrm{mol} \mathrm{mol}{ }^{-1}\right.$ photons $]$ & $A_{\max }\left[\mu \mathrm{mol}^{-2} \mathrm{~s}^{-1}\right]$ & $R^{2}[-]$ \\
\hline SOA & Moist & 8.4 & 0.34 & 7.9 & 0.50 & 0.062 & 34.2 & 0.59 \\
\hline SOA & Dry & 7.2 & 0.27 & 9.2 & 0.51 & 0.061 & 23.1 & 0.50 \\
\hline SOBS & Moist & 8.5 & 0.25 & 8.4 & 0.65 & 0.042 & 15.3 & 0.55 \\
\hline SOBS & Dry & 6.0 & 0.27 & 6.9 & 0.53 & - & - & - \\
\hline SOJP & Moist & 214.8 & 0.14 & 41.2 & 0.54 & 0.032 & 13.3 & 0.39 \\
\hline SOJP & Dry & 5.9 & 0.25 & 11.1 & 0.47 & 0.030 & 12.4 & 0.43 \\
\hline
\end{tabular}

$R$, ecosystem respiration; GEP, gross ecosystem productivity.

The parameters were fitted to data in Figure 8 for average $\left(\theta_{r}\right.$ at least or equal 0.5$)$ and low $\left(\theta_{r}\right.$ less than 0.5$)$ availability of soil water.

between nighttime $R$ and $T_{S}$ (at the 5 -cm depth) for all three sites. The data have been stratified into high and low availability of soil water. For the stratification, the threshold value of $\theta_{r}$ was set to 0.5 (compare Figure 3). Based on this threshold for the $7.5-\mathrm{cm}$ depth, $59 \%$ to $70 \%$ of the $2001-03$ growing-season data at SOA was classified as having low available soil water content. At SOBS and SOJP, the percentage of low soil moisture data was 0 (in 2002 ) to $39 \%$ and $28 \%$ to $62 \%$, respectively.

The influence of available soil moisture content was most pronounced at SOA. The soil temperature sensitivity of $R$ decreased in response to the drought. Similar findings have been reported by Reichstein and others (2002), who examined $R$ in two evergreen Mediterranean ecosystems. The correlation between total growing-season $R$ and total growingseason $P$ was high $\left(r^{2}=0.98\right)$ for the 4 years of the present study. At SOBS, the dependence on $\theta$ was not as strong but was still discernible, whereas at SOJP it was slightly more pronounced than at SOBS; the correlation between total growing-season $R$ and total growing-season $P$ was $r^{2}=0.86$ at SOBS and $r^{2}=0.40$ at SOJP. The parameters determining the $R$ (night) $-T_{s}$ relationship are given in Table 6 .

To study the relationship between GEP and $Q$, we separated the data into high and low availability of soil water based on $\theta$ at the $30-60-\mathrm{cm}$ depth because this is the layer that most likely controls GEP and $E$ at SOA. Again, the threshold value of $\theta_{r}$ was set to 0.5. At SOA, the relationship for dry years and years of high $\theta$ can be easily distinguished (Figure 8, right panel, and Table 6). Thus, the results of this study demonstrate the importance of measuring $\theta$ at depths greater than $60 \mathrm{~cm}$ for specific soil types and topography. Deep $\theta$ at the two conifer sites, in contrast, could not be stratified into dry and moist conditions because the differences were too small. Consequently, GEP at the two conifer sites showed no dependence on $\theta$. Using shallow $\theta$ for stratification did not alter this finding.

The relationship between monthly mean values of GEP and $E$ remained almost linear throughout the 4 years, with no dependence on the drought (Figure 9). The average values of water-use effi-

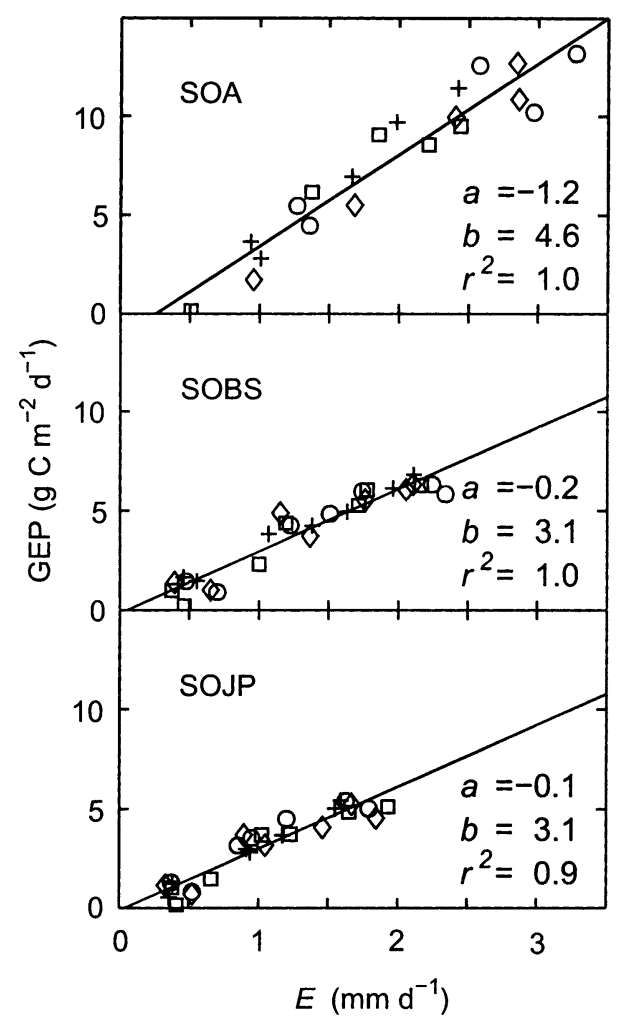

Figure 9. Growing-season gross ecosystem productivity (GEP) versus evapotranspiration $(E)$ (monthly averages) observed at the three sites in 2000 (diamonds), 2001 (circles), 2002 (squares), and 2003 (plus signs). a g C m$^{-2}$ $\mathrm{d}^{-1}$ ] denotes the intercept; $b\left[\mathrm{~g} \mathrm{C} \mathrm{m}^{-2} \mathrm{~d}^{-1} / \mathrm{mm} \mathrm{H}_{2} \mathrm{O} \mathrm{d}^{-1}\right.$ or $\mathrm{g} \mathrm{C} / \mathrm{kg} \mathrm{H}_{2} \mathrm{O}$ ] denotes the slope of the fitted linear relationship between GEP and $E$. 


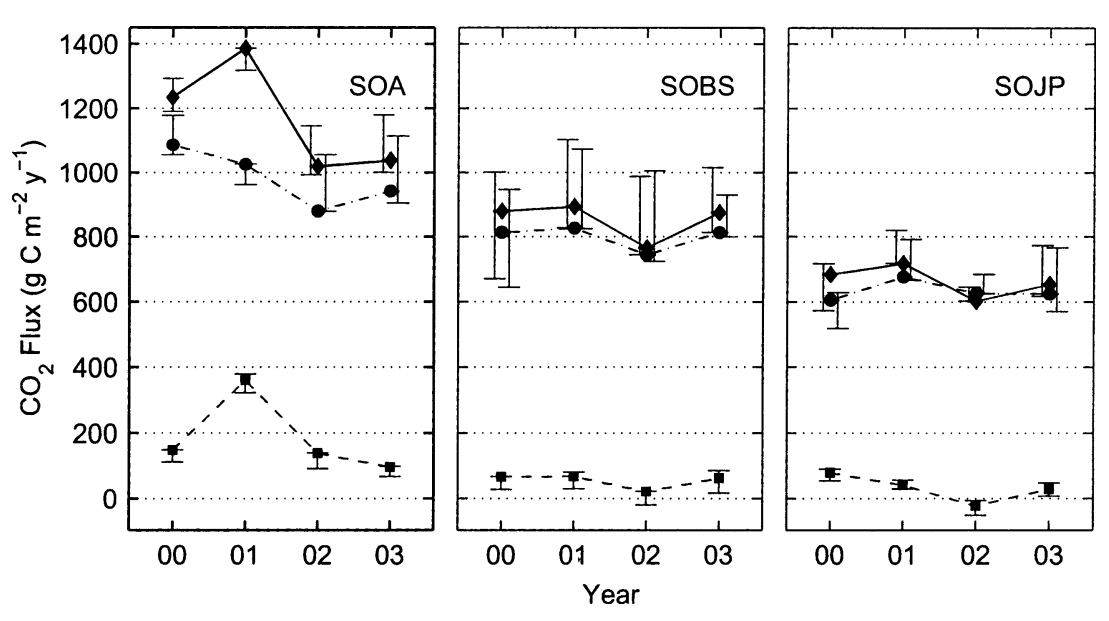

Figure 10. Annual net ecosystem productivity (NEP) (squares, dashed line), gross ecosystem productivity (GEP) (diamonds, solid line), and ecosystem respiration $(R)$ (circles, dash dotted line) for the three sites in 2000-03. Vertical bars denote the range of values derived from four gap-filling methods (see Table 2). Where required for clarity, the vertical bars for GEP and $R$ have been moved to the left and right, respectively.

Table 7. Annual Totals of Net Ecosystem Productivity (NEP), Ecosystem Respiration $(R)$, Gross Ecosystem Productivity (GEP), and Evapotranspiration $(E)$

\begin{tabular}{|c|c|c|c|c|c|}
\hline Site & Year & NEP $\left[g^{-2} \mathrm{~m}^{-2} \mathrm{y}^{-1}\right]$ & $R\left[\mathrm{~g} \mathrm{C} \mathrm{m}^{-2} \mathrm{y}^{-1}\right]$ & GEP $\left[\mathrm{g} \mathrm{C} \mathrm{m}^{-2} \mathrm{y}^{-1}\right]$ & $E\left[\mathrm{~mm} \mathrm{H}_{2} \mathrm{O} \mathrm{y}^{-1}\right]$ \\
\hline \multirow[t]{4}{*}{ SOA } & 2000 & 148 & 1086 & 1234 & 359 \\
\hline & 2001 & 361 & 1025 & 1386 & 375 \\
\hline & 2002 & 139 & 880 & 1019 & 279 \\
\hline & 2003 & 97 & 941 & 1038 & 269 \\
\hline \multirow[t]{4}{*}{ SOBS } & 2000 & 66 & 813 & 879 & 309 \\
\hline & 2001 & 68 & 826 & 894 & 329 \\
\hline & 2002 & 21 & 744 & 765 & 280 \\
\hline & 2003 & 62 & 813 & 875 & 296 \\
\hline \multirow[t]{4}{*}{ SOJP } & 2000 & 78 & 605 & 684 & 254 \\
\hline & 2001 & 41 & 676 & 717 & 237 \\
\hline & 2002 & -23 & 626 & 602 & 236 \\
\hline & 2003 & 29 & 624 & 653 & 222 \\
\hline
\end{tabular}

ciency (dGEP/dE-that is, the slope of the regression lines) were $4.62,3.12$, and $3.12 \mathrm{~g} \mathrm{C} \mathrm{kg}^{-1} \mathrm{H}_{2} \mathrm{O}$ for SOA, SOBS, and SOJP, respectively. Arain and others (2002), who analyzed data from SOA and SOBS for 1994-99, reported a similar value for SOBS $\left(2.82 \mathrm{~g} \mathrm{C} \mathrm{kg}^{-1} \mathrm{H}_{2} \mathrm{O}\right)$ but a significantly lower value for SOA $\left(2.85 \mathrm{~g} \mathrm{C} \mathrm{kg}^{-1} \mathrm{H}_{2} \mathrm{O}\right)$.

\section{Interannual Variability in Net Ecosystem Productivity}

Figure 10 shows the annual NEP, GEP, and $R$ at the three sites, as well as the range of these values derived from the four different gap-filling methods. Although the range is not negligible, we found that the temporal variation of these annual values is independent of the gap-filling method.

In 2000, SOA was a moderate sink for $\mathrm{CO}_{2}$, sequestering $148 \mathrm{~g} \mathrm{C} \mathrm{m}^{-2} \mathrm{y}^{-1}$ (Table 7). This is consistent with the values reported over the previous 6 years, during which there were no significant shortages of soil moisture (Black and others 2000). By comparison, the two conifer sites, SOBS and SOJP, were weak sinks for $\mathrm{CO}_{2}$, sequestering 66 and $78 \mathrm{~g} \mathrm{C} \mathrm{m}^{-2} \mathrm{y}^{-1}$, respectively, in normal years. This finding is in good agreement with the analysis of Griffis and others (2003).

In 2001, SOA sequestered 2.5 times more $C$ than in 2000 (Figure 10 and Table 7), which was the highest annual $\mathrm{CO}_{2}$ uptake in the 9 years of flux measurements at this site. This extraordinary increase resulted from both very high GEP due to the early start of photosynthesis and reduced $R$ due to the drought. The effect of the early start of GEP (approximately $100 \mathrm{~g} \mathrm{C} \mathrm{m}^{-2}$ ) can be assessed by comparing Figures 10 and 6 . The GEP values for SOBS and SOJP in 2001 were very similar to the respective values in 2000 because the conifers did not benefit from the early spring. Also, $R$ was not reduced in 2001 because the conifer sites were not significantly affected by the drought. Thus, the net 
$\mathrm{CO}_{2}$ uptake by the conifers remained the same as in 2000 (within the range of uncertainty).

In 2002, annual $R$ for all three sites was lower than in 2001. This reduction was mainly due to the cold spring (the coldest of the 4 years); however, for SOA the drought also had a significant effect (compare Figures 6 and 10). Gross ecosystem productivity dropped sharply from 2001 at SOA due to both the cold spring (that is, late leaf emergence) and the drought; it also dropped significantly at the two conifer sites but this change also appeared to be mainly a result of the cold spring (Figures 6 and 10). Net ecosystem productivity was in the same range as in 2000 at SOA, and the two conifer sites registered the lowest NEP of the 4 years. Thus, SOA was a sink for $\mathrm{CO}_{2}$, SOBS was close to neutral, and SOJP was a small source of $\mathrm{CO}_{2}$. Since the beginning of year-round $\mathrm{CO}_{2}$ flux measurement at the conifer sites, 2002 was the first year in which SOJP was a $\mathrm{CO}_{2}$ source. This finding is consistent with other studies that have reported the possibility that mature boreal forests are significant sources of $\mathrm{CO}_{2}$ (for example, Lindroth and others 1998; Milyukova and others 2002).

Finally, in 2003, $R$ at SOA was only slightly higher than in 2002 (likely due to the higher spring temperature) and GEP remained low due to the drought. Consequently, annual $\mathrm{C}$ sequestration at SOA was slightly less than in 2002 (Figure 10). Although the conifer sites had a reduction in $P$ that was similar to that recorded at SOA, they sequestered C at rates similar to 2000 and 2001 . At SOBS, it would probably require several years of precipitation as low as in 2003 for there to be a significant drop in $\theta$ deep in the root zone-enough to cause a noticeable drop in GEP and $R$. Griffis and others (2003) speculated that drier conditions at SOBS would affect NEP by reducing the photosynthetic contribution of the moss understory. However, in this study, the drought conditions exerted almost no effect on GEP at SOBS (Figure 6)-even in 2003, when annual $P$ was much lower than in 2000 (Figure 2). It would require a watershed-scale hydrologic modeling study to estimate the number of years of sustained drought that would be required before an impact on GEP and $R$ would be seen at SOBS. At SOJP, it appears that the benefit of high rainfall is lost due to the low water-holding capacity of the sandy soil, which results in extra water draining from the root zone. Consequently, there are generally low soil moisture conditions at this site regardless of total $P$. However, conifer stands may also be affected by a drought, depending on the soil characteristics and topography. For example, when Hollinger and others (1998) examined a conifer site (Larix gmelinii Rupr.) in Siberia that was located in a climatic zone similar to that of the sites in the present study, they found that the $\mathrm{CO}_{2}$ uptake declined after several days of drought.

When we compared total $\mathrm{CO}_{2}$ uptake at the three sites between 2000 and 2003, it was clear that the deciduous stand sequestered more $\mathrm{C}$ than the conifer stands, even though it was the site most affected by the drought. Kimbal and others (2000) found that aspen stands covered only $12 \%$ to $13 \%$ of the southern study area (SSA) of BOREAS. Wet conifer stands (mainly black spruce) were the dominant forest type, representing $46 \%$ of the SSA, followed by dry conifer stands (mainly jack pine), which covered $20 \%$ of the area. If we assume that these proportions and the $\mathrm{C}$ uptake at SOA, SOBS, and SOJP are representative, these three forest types would have accounted for about $28 \%, 48 \%$, and $24 \%$, respectively, of the $\mathrm{C}$ sequestered in the southern boreal forest in western Canada in 2000. During the worst drought year (2003), these percentages became $25 \%, 62 \%$, and $13 \%$, respectively. Thus, on the one hand, the stabilizing character of the widespread black spruce stands might help to reduce the impact of a drought. On the other hand, the $\mathrm{C}$ balance of the southern boreal forest may be highly influenced by cold springs, which affected all three forest types in our study period.

\section{Summary AND Conclusions}

In this study, we analyzed EC flux measurements of $\mathrm{CO}_{2}$ and climate data obtained from three southern boreal forests-a deciduous (aspen) stand and two conifer stands (black spruce and jack pine). The time series included a normal climate year, which was followed by 3 years when the stands were affected by drought. The springs of the lst and 3rd drought years were warm, whereas the spring of the 2nd drought year was cold. The study separated the impacts of drought and variable spring temperatures on GEP, $R$, and NEP.

Although this was a major regional drought, there was significant spatial variability in precipitation over distances of $80-100 \mathrm{~km}$. The reduction in precipitation (approximately 50\%) was very similar in each of the 3 years at the deciduous site whereas at the conifer sites summer rain diminished the impact of the drought in the first 2 years. In the 3rd year, the drought was equally severe at all three sites. This shows that sites within the BERMS study area cannot be assumed to be exposed to the same precipitation. This study illus- 
trates that knowledge of the spatial variation in the regional water balance is essential for assessment of the impact of drought on forest ecosystems.

The drought significantly affected the annual C budget of the deciduous forest. During the lst drought year, low soil water content significantly decreased $R$ whereas GEP was unaffected. In the 2nd and 3rd years of the drought, the reduction in $E$ and GEP indicated the occurrence of tree water stress. The conifer sites, on the other hand, showed very limited response to the low growing-season $P$. The relative extent of drought effects on $R$ and GEP, and thus on the resulting $\mathrm{C}$ balance, depended on soil characteristics and the topographic location of the forest. In ecosystems where the water table is controlled by subsurface-lateral water flow as a result of topographic position (for example, sites in a relatively low elevation location, such as SOBS), the trees are not much affected by a reduction in precipitation. In ecosystems where little water is stored due to the coarse texture of the soil (for example, SOJP), the benefit of rainfall events is small and the vegetation is not greatly affected by drought. However, a comparison of the total $\mathrm{CO}_{2}$ uptake at the three sites between 2000 and 2003 shows that the deciduous stand sequestered more $\mathrm{C}$ than the conifer stands, even though it was affected most by the drought. So far, it cannot be assumed that $R$, GEP and LAI are not completely independent of the impact of the previous year's drought. The quantification of these possible antecedent effects is part of current research.

As had also been found in previous studies, warm springs significantly increased GEP at the aspen site. This factor, together with the reduction in $R$ as a result of low soil moisture content in the lst year of the drought, resulted in the highest annual $C$ sequestration in the 9 years of flux measurement at this site. In contrast to the deciduous site, GEP at the conifer sites did not benefit from the warm spring due to earlier timing of factors triggering the start of the growing season. The cold spring, however, affected all three sites similarly, such that photosynthesis began later at all sites. The reduction in $\mathrm{CO}_{2}$ sequestration in spring caused one of the conifer sites (SOJP) to be a source of $\mathrm{CO}_{2}$ in 2002 for the 1st year since the beginning of year-round $\mathrm{CO}_{2}$ flux measurement at this site, whereas the $\mathrm{CO}_{2}$ uptake at the other conifer site (SOBS) decreased to near zero.

\section{ACKNOWLEDGEMENTS}

Financial support was provided by the Climate Research Branch of the Meteorological Service of Canada, the Canadian Forest Service, Parks Can- ada, the Action Plan 2000 on Climate Change, the Program of Energy Research and Development, the Climate Change Action Fund, through funding for the Fluxnet Canada Research Network (Natural Sciences and Engineering Research Council of Canada, BioCap Canada, the Canadian Foundation for Climate and Atmospheric Science), the Swiss National Science Foundation, and the Swiss Federal Institute of Technology. We sincerely thank Barry Goodison and Bob Stewart for their support and encouragement. We gratefully acknowledge the assistance, support, and suggestions of Dell Bayne, Bruce Cole, Joe Eley, Steve Enns, Charmaine Hrynkiw, Rachhpal Jassal, Rick Ketler, Shawn O`Neil, Andrew Sauter, Dave Wieder, and two anonymous reviewers.

\section{REFERENCES}

Albritton DL, Meira Filho LG, Cubasch U, Dai X, Ding Y, Griggs DJ, Hewitson B, and others. 2001. Technical summary of the Working Group I report: climate change 2001. Technical Report 21-83. Geneva: The Scientific Basis. Intergovernmental Panel on Climate Change, World Meteorological Organization.

Arain A, Black TA, Barr AG, Jarvis PG, Massheder JM, Verseghy DL, Nesic Z. 2002. Effects of seasonal and interannual climate variability on net ecosystem productivity of boreal deciduous and conifer forests. Can J For Res 32:878-91.

Aubinet M, Grelle A, Ibrom A, Rannik U, Moncrieff J, Foken T, Kowalski AS, and others.2000. Estimates of the annual net carbon and water exchange of forests: the EUROFLUX methodology. Adva Ecol Res 30:113-75.

Baldocchi DD. 1997. Measuring and modeling carbon dioxide and water vapour exchange over a temperate broad-leaved forest during the 1995 summer drought. Plant Cell Environ 20:1108-22.

Baldocchi DD, Vogel CA. 1997. Seasonal variation of energy and water vapor exchange rates above and below a boreal jack pine forest canopy. J Geophys Res 102:28939-51.

Baldocchi DD, Vogel CA, Hall B. 1997. Seasonal variation of carbon dioxide exchange rates above and below a boreal jack pine forest canopy. Agric For Meteorol 83:147-70.

Baldocchi DD, Black TA, Curtis PS, Falge E, Fuentes JD, Granier $\mathrm{A}, \mathrm{Gu} \mathrm{L}$, and others.2005. Predicting the onset of net carbon uptake deciduous forests with soil temperature and climate data: a synthesis of FLUXNET data. Int J Biometeorol 49:37787.

Barr AG, Black TA, Hogg EH, Kljun N, Morgenstern K, Nesic Z. 2004. Inter-annual variability in the leaf area index of a boreal aspen-hazelnut forest in relation to net ecosystem production. Agric For Meteorol 126:237-55.

Barr AG, Black TA, Theede A, Griffis TJ, Kljun N, Morgenstern K, Nesic Z. 2007. Climatic controls on the carbon and water balances of a boreal aspen forest, 1994-2003. Global Change Biol 13:561-576.

Bernier PY, Bartlett P, Black TA, Barr AG, Kljun N, McCaughey JH. 2006. Drought constraints on transpiration and canopy conductance in mature aspen and jack pine stands. Agric For Meteorol 140:64-78. 
Black TA, den Hartog G, Neumann H, Blanken P, Yang P, Russell C, Nesic Z, and others.1996. Annual cycles of water vapour and carbon dioxide fluxes in and above boreal aspen forest. Global Change Biol 2:219-29.

Black TA, Chen WJ, Barr AG, Arain MA, Chen Z, Nesic Z, Hogg $\mathrm{EH}$, and others.2000. Increased carbon sequestration by a boreal deciduous forest in years with a warm spring. Geophys Res Lett 27:1271-4.

Blanken PD, Black TA, Yang PC, Neumann HH, Nesic Z, Staebler R, den Hartog G, and others. 1997. Energy balance and canopy conductance of a boreal aspen forest: partitioning overstory and understory components. J Geophy Res 102:28915-28.

Borken W, Xu Y-J, Brumme R, Lamersdorf N. 1999. A climate change scenario for carbon dioxide and dissolved organic carbon fluxes from a temperate forest soil: drought and rewetting effects. Soil Sci Soc Am J 63:1848-55.

Borken W, Savage K, Davidson EA, Trumbore SE. 2006. Effects of experimental drought on soil respiration and radiocarbon efflux from a temperate forest soil. Global Change Biol 12:177-193.

Burns RM, Honkala BH, Eds. 1990. Silvics of North America: 1. conifers; 2. hardwoods. Agriculture Handbook 654. Washington (DC): US Department of Agriculture, Forest Service. $877 \mathrm{p}$.

Campbell GS, Norman JM. 1998. An introduction to environmental physics. New York: Springer, p 286.

Drewitt GB, Black TA, Nesic Z, Humphreys ER, Jork EM, Swanson R, Ethier GJ, and others.2002. Measuring forest floor $\mathrm{CO}_{2}$ fluxes in a Douglas-fir forest. Agric For Meteorol 110:299-317.

Foti S, Cosentino L, Patan C, Copani V, Sanzone E. 2003. Plant indicators of available soil water in the perennial herbaceous crop Miscanthus $\times$ giganteus Greef et Deu. Agronomie 23:29-36.

Gaumont-Guay D, Black TA, Griffis TJ, Barr AG, Morgenstern K, Jassal RS, Nesic Z. 2006. Influence of temperature and drought on seasonal and interannual variations of soil, bole and ecosystem respiration in a boreal aspen stand. Agric For Meteorol 140:203-219.

Gower ST, Vogel JG, Norman JM, Kucharik CJ, Steele SJ, Stow TK. 1997. Carbon distribution and aboveground net primary production in aspen, jack pine, and black spruce stands in Saskatchewan and Manitoba, Canada. J Geophys Res 102:29029-41.

Griffis TJ, Black TA, Morgenstern K, Barr AG, Nesic Z, Drewitt GB, Gaumont-Guay D, and others.2003. Ecophysiological controls on the carbon balances of three southern boreal forests. Agric For Meteorol 117:53-71.

Griffis TJ, Black TA, Gaumont-Guay D, Drewitt GB, Nesic Z, Barr AG, Morgenstern K, and others.2004. Seasonal variation and partitioning of ecosystem respiration in a southern boreal aspen forest. Agric For Meteorol 125:207-223.

Hogg EH. 1997. Temporal scaling of moisture and the forestgrassland boundary in western Canada. Agric For Meteorol 84:115-22.

Hollinger DY, Kelliher FM, Schulze E-D, Bauer G, Arneth A, Byers J-N, Hunt J-E, and others.1998. Forest-atmosphere carbon dioxide exchange in eastern Siberia. Agric For Meteorol 90:291-306.
Jarvis PG, Massheder JM, Hale SE, Moncrieff JB, Rayment M, Scott SL. 1997. Seasonal variation of carbon dioxide, water vapor, and energy exchanges of a boreal black spruce forest. J Geophys Res 102:28953-66.

Keeling CD, Chin JFS, Whorf TP. 1996. Increased activity of northern vegetation inferred from atmospheric $\mathrm{CO}_{2}$ Measurements. Nature 382:146-9.

Kimbal JS, Keyser AR, Running SW, Saatchi SS. 2000. Regional assessment of boreal forest productivity using an ecological process model and remote sensing parameter maps. Tree Physiol 20:761-75.

Kljun N, Rotach MW, Calanca P. 2004. A simple parameterisation for flux footprint predictions. Bound-Lay Meteorol 112:503-23.

Landsberg JJ, Gower ST. 1997. Applications of physiological ecology to forest management. San Diego: Academic Press.

Lindroth A, Grelle A, Moren AS. 1998. Long-term measurements of boreal forest carbon balance reveal large temperature sensitivity. Global Change Biol 4:443-50.

Lotsch A, Friedl MA, Anderson B, Tucker CJ. 2005. Response of terrestrial ecosystems to recent Northern Hemispheric drought. Geophys Res Lett 32:L06705, 1-5.

McClone MS. 1996. When history matters: scale, time, climate and tree diversity. Global Ecol Biogeogr Lett 5:309-14.

Milyukova IM, Kolle O, Varlagin AV, Vygodskaya NN, Schulze ED, Lloyd J. 2002. Carbon balance of a southern taiga spruce stand in European Russia. Tellus Series B 54:429-42.

Morgenstern K, Black TA, Humphreys ER, Griffis TJ, Drewitt GB, Cai T, Nesic Z, and others.2004. Sensitivity and uncertainty of the carbon balance of a Pacific Northwest Douglas-fir forest during an El Niño/La Niña cycle. Agric For Meteorol 123:201-19.

Reichstein M, Tenhunen JD, Roupsard O, Ourcival J-M, Rambal S, Miglietta F, Peressotti A, and others.2002. Severe drought effects on ecosystem $\mathrm{CO}_{2}$ and $\mathrm{H}_{2} \mathrm{O}$ fluxes at three Mediterranean evergreen sites: revision of current hypotheses?. Global Change Biol 8:999-1017.

Ryan MG, Lavigne MB, Gower ST. 1997. Annual carbon cost of Autotrophic respiration in boreal forest ecosystems in relation to species and climate. J Geophys Res 102:28871-83.

Sellers PJ, Hall FG, Kelly RD, Black TA, Baldocchi D, Berry J, Ryan M, and others.1997. BOREAS in 1997: experiment overview scientific results, and future directions. J Geophys Res 102:28731-69.

Tanner CB, Thurtell GW. 1969. Anemoclinometer measurements of Reynolds stress and heat transport in the atmospheric boundary layer. Research and Development Technical Report ECOM66-G22F. Madison (WI): University of Wisconsin.

Webb EK, Pearman GI, Leuning R. 1980. Correction of Flux measurements for density due to heat and water vapour transfer. Q J Roy Meteor Soc 106:85-100.

Yang PC, Black TA, Neumann HH, Blanken PD. 1999. Spatial and temporal variability of $\mathrm{CO}_{2}$ concentration and flux in a boreal aspen forest. J Geophys Res-Atmos 104:27653-61. 